\title{
sciforum
}

\section{ISOLATION AND CHARACTERIZATION OF BACTERIAL CONSORTIA WITH CAPACITY TO DEGRADE HYDROCARBONS}

Everardo Briseño Silvaa, Valentin Toro Castilloa, Pedro Damián Loeza Laraa, José Antonio Aguilar Lópeza, Rafael Jiménez Mejíaa

Universidad de La Ciénega del Estado de Michoacán de Ocampo, Genómica Alimentaria. Av. Universidad 3000, col. Lomas de la Universidad, Sahuayo, Michoacán.C.P. 59103.rijimenez@ucienegam.edu.mx

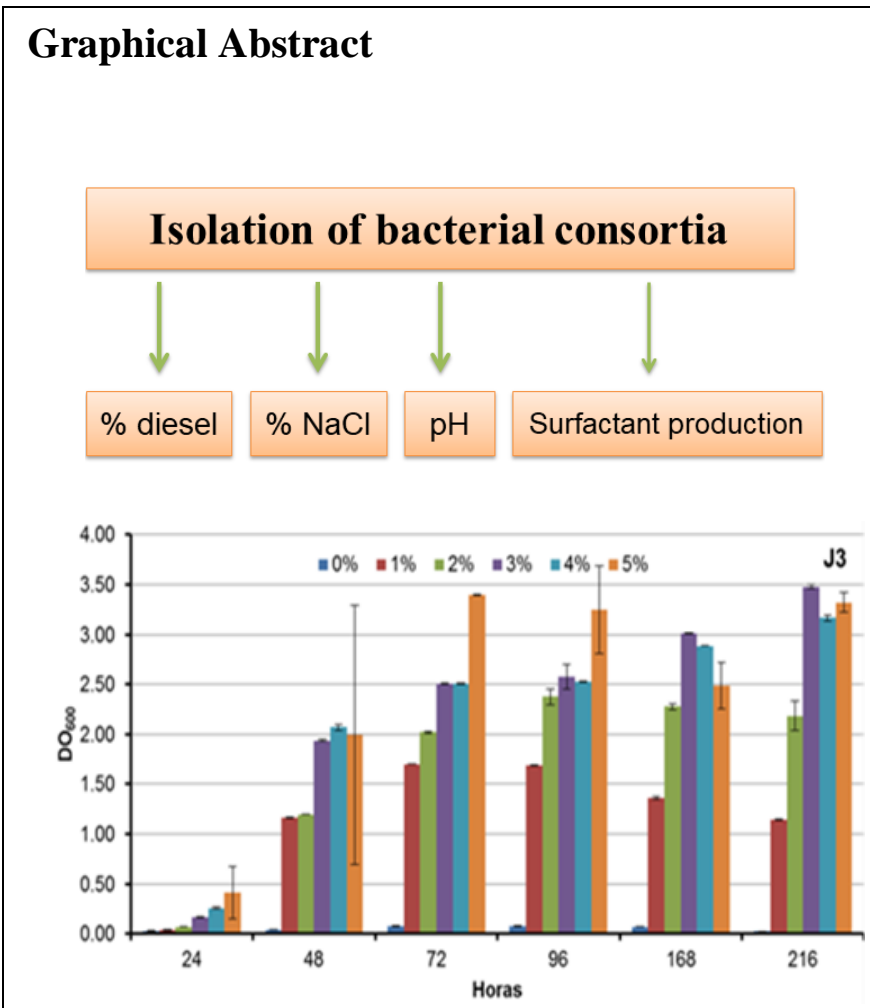

Figure 1. Growth of bacterial consortium $\mathrm{J} 3$ in different concentrations of diesel.

\section{Abstract.}

The increasing use of hydrocarbons has generated several environmental problems due to accidents during the extraction, transportation, refining, storage and use of said compounds. Diesel is a complex mixture of alkanes and aromatics, which due to its wide use has become a very frequent pollutant of water and soil. Therefore, it is necessary to explore alternatives for the degradation of said pollutants. The purpose of this work is to analyze the optimal conditions for the degradation of diesel by bacterial consortiums from polluted soils, as well as to evaluate the production of surfactants. The bacterial consortiums (J3 and S3) were obtained from soil samples and selected in diesel as the sole carbon source, in addition, the data of the growth kinetics obtained to date in different concentrations of diesel indicate that the two bacterial consortiums use it more at 3 and $4 \%$. On the other hand, at a pH of 7 and 8 in the 


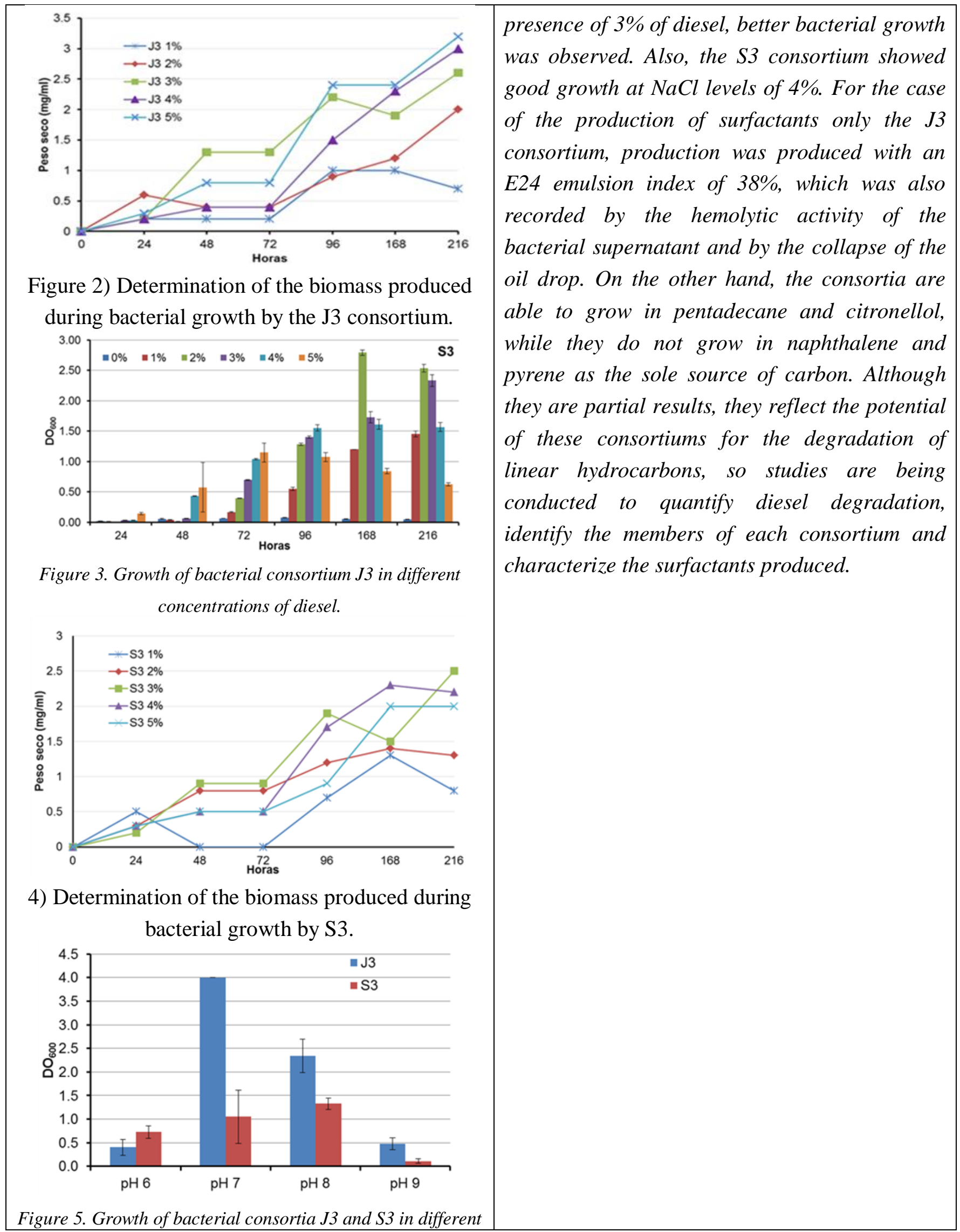




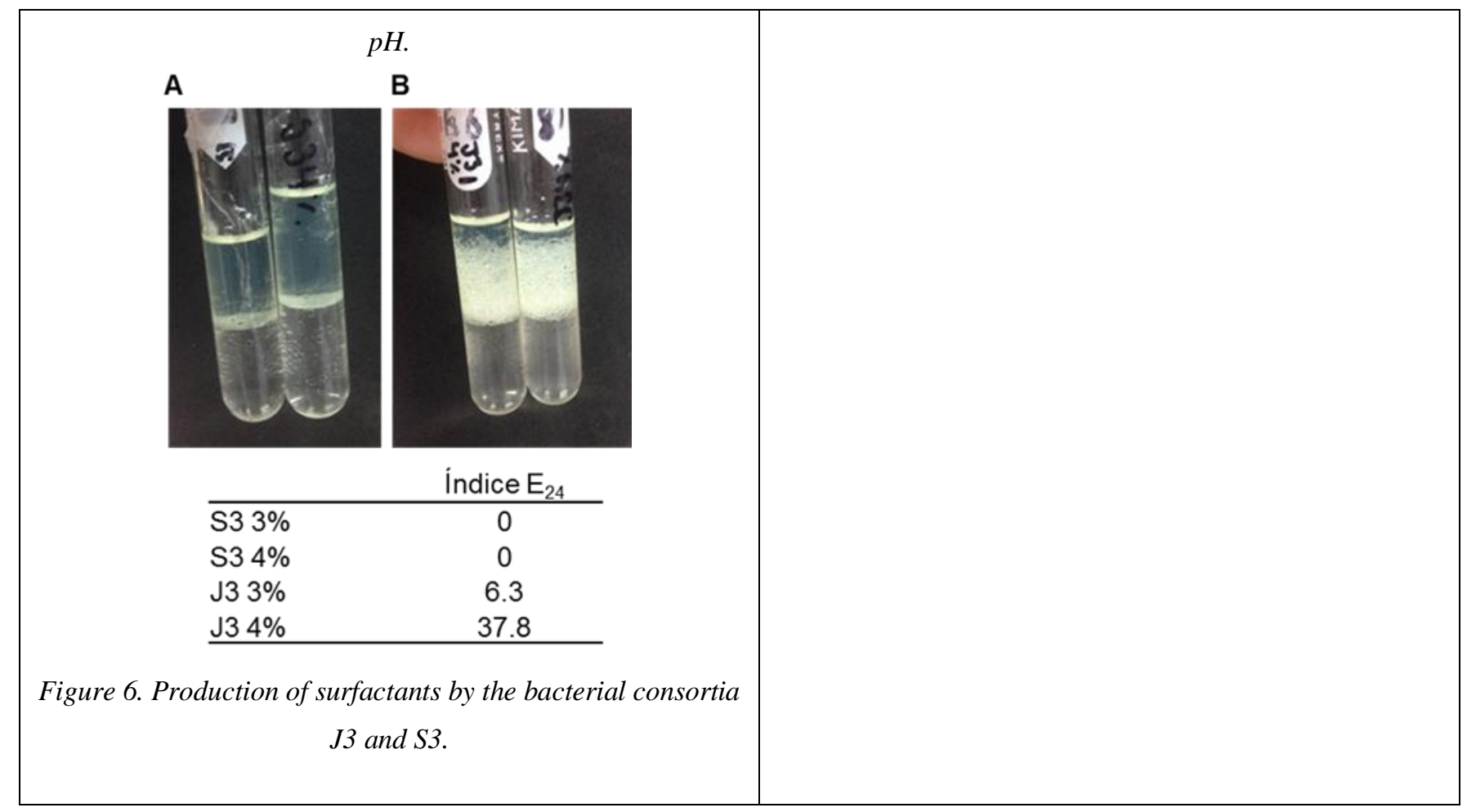

\section{Introduction (optional)}

The exploration, production and transportation of oil has increased in recent years and is expected to increase further in the next. As a consequence, spills and oil pollution are expected to increase as well (Liu et al., 2017). Diesel is one of the products obtained from the refining of oil, which is a complex mixture of linear, branched, cyclic and aromatic hydrocarbons, which has been considered one of the main organic pollutants with harmful effects on living beings (Gallego et al. al., 2001). Hydrocarbons are very frequent pollutants of soil and water, so that their removal is one of the main topics in environmental sciences (Arslan et al., 2014). Although hydrocarbons have toxic effects for many organisms, many of them also have the capacity to use them as a carbon source and make bioremediation of hydrocarbons a viable option. The degradation of hydrocarbons by microbial communities represents a viable and cheap option for the removal of said compounds in diverse environments. The efficiency of bioremedication is influenced by several factors, among which are environmental factors such as $\mathrm{pH}$, temperature and availability of nutrients, among others (Palanisamy et al., 2014). To date, bacteria with the capacity to degrade hydrocarbons (diesel) have been described, among which are Pseudomonas aeruginosa, Bacillus subtilis, Bacillus megaterium, Corynebacterium kutscher (Muthukamalam et al., 2017). In this work, the capacity of two bacterial consortiums for diesel degradation was analyzed, as well as the production of surfactants by said partners.

\section{Materials and Methods (optional)}


Isolation of bacteria. Samples of $1 \mathrm{~kg}$ of soil were collected in two workshops of diesel engines, at a depth of between 5 and $15 \mathrm{~cm}$. For the enrichment of bacteria with potential for the degradation of hydrocarbons, the soil samples were homogenized and $10 \mathrm{~g}$ of each were deposited in a flask with 90 $\mathrm{ml}$ of minimal M9 medium and as the only carbon source $1 \%$ of commercial diesel (Pemex ). The flasks were incubated at $30^{\circ} \mathrm{C}$ and the growth monitored for 15 days. From these primary cultures 50 $\mathrm{ml}$ of M9 medium added with $1 \%$ diesel were inoculated and incubated for 7 days at $30^{\circ} \mathrm{C}$, the process was repeated once more.

Effect of diesel concentration on bacterial growth. With bacterial consortiums named J3 and S3 growth kinetics were performed in basal salt medium (MBS) supplemented with 0,1, 2, 3, 4 and 5\% of diesel as the sole carbon source, bacterial growth was determined by measuring the optical density at $600 \mathrm{~nm}$ and dry weight at 24, 48, 72, 96, 168 and $216 \mathrm{~h}$.

Effect of $\mathbf{p H}$ and salt. The effect of $\mathrm{pH}$ on diesel degradation was also analyzed, for which the $\mathrm{J} 3$ and $\mathrm{S} 3$ consortiums were grown for 7 days in MBS with 3\% diesel and $\mathrm{pH}$ of 6, 7, 8 and 9. On the other hand, the effect of salt concentration $(\mathrm{NaCl})$ on bacterial growth in the presence of $3 \%$ diesel, the concentrations tested were $0,0.1,0.5,1,2$ and $4 \%$.

Production of surfactants. The production of surfactants in the bacterial consortiums was analyzed in MBS supplemented with 3 and $4 \%$ of diesel. The quantification of the production of surfactants was carried out by means of the emulsification index at $24 \mathrm{~h}$, hemolytic activity, collapse of the oil drop and oil displacement test.

Studies in process. Experiments are underway to quantify diesel degradation, analyze the types of hydrocarbons that they prefer to use as a carbon source (aromatic or aliphatic), characterize the surfactants produced by the bacterial consortia and identify the members of each consortium.

\section{Results and Discussion (optional)}

Two soil samples were collected, from which the bacterial consortiums J3 and S3 were obtained. These bacteria are able to use diesel as the sole carbon source. In general, the concentrations of diesel in which the best bacterial development was observed were between 3 and $4 \%$, which was monitored every $24 \mathrm{~h}$ by measuring the OD at $600 \mathrm{~nm}$ (Figure 1 and 3) and the determination of biomass in dry weight form (Figure 2 and 4). It was also determined that the $\mathrm{pH}$ at which the bacterial consortia showed better growth in the presence of 3\% diesel was 7 for the $\mathrm{J} 3$ consortium and 8 for S3 (Figure 5). Likewise, the two consortiums were able to use diesel as the sole carbon source in the presence of up to $4 \% \mathrm{NaCl}$ in the culture medium. While, the analysis of the production of surfactants revealed that only the $\mathrm{J} 3$ consortium was able to produce them in greater quantity at the $4 \%$ concentration of diesel, with an emulsification index at $24 \mathrm{~h}$ of $38 \%$ (Figure 6B). This was also analyzed by the hemolytic capacity and the collapse of oil droplets. 


\section{Conclusions (optional)}

According to the results obtained to date, the two bacterial consortiums are able to use diesel as the sole carbon source, which indicates that they have potential for the degradation of hydrocarbons. The microbial growth was better at concentrations of 3 and $4 \%$ of diesel and at a pH of 7 . The data obtained so far indicate that the J3 consortium grows better than S3 in the presence of diesel, which is possibly due to the fact that it produces surfactants that favor the assimilation of hydrocarbons.

\section{References (mandatory)}

. 1. Arslan M, Afzal M, Amin I, Iqbal S, Khan QM. Nutrients can enhance the abundance and expression of alkane hydroxylase CYP153 gene in the rhizosphere of ryegrass planted in hydrocarbonpolluted soil. PLoS ONE, Vol. 9, No. 10, p. 1-7, 2014.

2. Gallego JL, Loredo J, Llamas JF, Vázquez F, Sánchez J. Bioremediation of diesel-contaminated soils: evaluation of potential in situ techniques by study of bacterial degradation. Biodegradation, Vol. 12, No. 5, 325-335, 2001.

3. Liu J, Bacosa HP, Liu Z. Potential environmental factors affecting oil-degrading bacterial populations in deep and surface waters of the northern Gulf of Mexico. Frontiers in Microbiology, Vol. 7, p. 1-14, 2017.

4. Palanisamy N, Ramya J, Kumar S, Vasanthi NS, Chandran P, Khan S. Diesel biodegradation capacities of indigenous bacterial species isolated from diesel contaminated soil. J Environ Health Sci Eng, Vol. 12, p. 1-8, 2014.

5. Santhakumar M, Sivalingam S, Dharmapal D, Sadras SR. Characterization of dioxygenases and biosurfactants produced by crude oil degrading soil bacteria. Brazilian Journal of Microbiology, Vol. 48, No. 4, p. 637-647, 2017. 